\title{
Composite Adverse Event Outcome in Pediatric Cancer Patients with Prolonged Febrile Neutropenia
}

\author{
Muhammad Matloob Alam \\ Department of Pediatrics \& Child Health, Aga Khan University, Karachi, Pakistan
}

\begin{abstract}
Objective: Pediatric cancer patients with prolonged febrile neutropenia have increased risk for severe, recurrent or new bacterial and fungal infection. The aim of this study was to identify the risk factors associated with adverse outcomes in this group.

Methods: We retrospective analyzed the clinical data of 135 hospitalizations of pediatric cancer patients with prolonged febrile neutropenia from a tertiary health care center of Pakistan.

Results: The mean age of the study population was $7.3 \pm 4.1$ years. There were $98(72.6 \%)$ males and $37(27.4 \%)$ females. Acute leukemia with 88 patients (65.2\%) was the most common diagnosis followed by lymphomas 19 patients (14.1\%) and solid tumors. Cause of febrile neutropenia was identified in only 58 (43.0\%) patients, out of them blood stream infections were found in 22 cases (16.3\%), pneumonia in 15 (11.1\%), fungal infection in 13 (9.6\%), infectious diarrheas in $5(3.7 \%)$ and urinary tract infection (UTI) in $3(2.2 \%)$ of cases. The composite adverse event outcome was observed in $28(20.7 \%)$ of patients, with in-hospital mortality occurring in 7 (5.2\%), Pediatric intensive care unit (PICU) admission occurring in $12(8.9 \%)$ and inotropic support was required in 9 (6.7\%). On logistic regression analysis AML (Adjusted odds ratio (AOR), 7.6; $P<0.001)$, neutropenia $<50 / \mathrm{mm}^{3}(A O R, 10.8 ; p<0.001)$, platelets count $<50,000 / \mathrm{mm}^{3}$ ( $A O R, 5.2$; $p<0.001), B S I(A O R, 2.3 ; p 0.05)$ and fungal infection $(A O R, 4.3 ; p<0.001)$ were found as independent risk factors for composite adverse event outcome in pediatric cancer patients with prolonged febrile neutropenia.
\end{abstract}

Conclusions: AML, severe myelosuppression, blood stream infections and fungal infection were identifiable risk factors associated with development of adverse event outcome in pediatric cancer patients with prolonged febrile neutropenia. J Microbiol Infect Dis 2016;6(2): 69-73

Key words: Febrile neutropenia, pediatric, oncology, adverse outcome

\section{Uzamış Febril Nötropeni ile Pediatrik Kanser Hastalarında Karma Olumsuz Durum Sonu}

\section{ÖZET}

Amaç: Uzamış febril nötropeni pediatrik kanserli hastalarında ağır seyirli yeni tanı veya tekrarlayan bakteri ve mantar enfeksiyonu riski artmıştır. Bu çalışmanın amacı, bu grupta olumsuz sonuçlarla ilişkili risk faktörlerini belirlemektir.

Yöntemler: Pakistan'ta bir üçüncü basamak sağılık merkezine uzamış febril nötropeni nedeni ile izlenen pediatrik kanser hastalarının 135 hastane yatış epizotu retrospektif olarak analiz edildi.

Bulgular: Çalışma grubunun yaş ortalaması 7,3 $\pm 4,1$ yıl idi. Hastaların 98'i $(\%$ 72,6) erkek ve 37'si $(\%$ 27,4) kadındı. Akut lösemi 88 hastada (\% 65,2) ile birinci sırada, lenfoma 19 hasta $(\% 14,1)$ ile ikinci sırada idi ve diğer hastalarda solid organ tümörleri en sık görülen tanı olarak saptandı. Febril nötropenin nedeni sadece 58 (\% 43,0) hastada tanımlandı. Bu hastalardan 22 olguda (\% 16,3) kan akımı enfeksiyonu (KAE), 15 hastada pnömoni (\% 11,1), fungal infeksiyon 13 (\% 9,6) hastada, ve enfeksiyöz diyare 5 hastada $(\% 3,7)$ ve üriner sitem enfeksiyonu $3(\% 2,2)$ hastada saptandı. Karma olumsuz durumlar $28(\% 20,7)$ hastada görüldü. Hastanede ölüm $7(\%$ 5,2) hastada, pediyatrik yoğun bakıma yatış $12(\%$ 8,9) hastada ve inotrop ilaç desteğine ihtiyaç $9(6,7)$ hastada saptandı. Lojistik regresyon analizi sonucunda akut miyelositer lösemi (Atfedilebilir Risk Oranı (ARO), 7,6; $p<0,001$ ), nötropeni $<50 / \mathrm{mm}^{3}$ (ARO, 10,8; $\left.p<0,001\right)$, trombosit sayısı $<50.000 / \mathrm{mm}^{3}$ (ARO, 5,2; $\left.<<0,001\right)$, KAE (ARO, 2,3; $\left.p=0,05\right)$ ve mantar enfeksiyonu (ARO, 4.3; $p<0,001)$ uzamış febril nötropenili pediatrik kanser hastalarında komkompozit advers olay sonuçlar için bağımsız risk faktörleri olarak bulundu.

Sonuç: AML, şiddetli miyelosupresyon, kan akımı enfeksiyonları ve mantar enfeksiyonu tanımlanabilir risk faktörleri olan Grubu Derneği'nden-bir- uzamış febril nötropeni olan pediatrik kanser hastalarında advers olay sonucu gelişmesi ile

Anahtar kelimeler: Febril nötropeni, pediatrik onkoloji, olumsuz sonuç

Correspondence: Muhammad Matloob Alam, Pediatric Hematology \& Oncology

Department of Paediatrics \& Child Health Aga Khan University Hospital Stadium Road, PO Box 3500, Karachi -74800, Pakistan

Email: dr.matloobalam@hotmail.com

Received: 16.09.2015, Accepted: 07.01.2016

Copyright (C) Journal of Microbiology and Infectious Diseases 2016, All rights reserved 


\section{INTRODUCTION}

Despite major advances in the understanding, established guidelines and recommendations for the treatment of febrile neutropenia (FN), prolonged neutropenia continues to be a significant cause of morbidity and mortality in pediatric patients with cancer [1-3].

In recent years, several studies from developed countries have evaluated the risk factors for poor outcomes among pediatric cancer patients (PCP) and helped to establish the current guidelines for the treatment of FN [4-6]. However, no data available from developing countries to identify the risk factors associated with development of adverse outcomes in pediatric patients with prolonged febrile neutropenia (PFN). This study was carried out to describe the composite adverse event outcomes and identify the associated risk factors in PCP with PFN at a tertiary health care center of Pakistan.

\section{METHODS}

\section{Study Design and Setting}

This is a retrospective study analyzing the clinical data of all children admitted with or who developed prolonged febrile neutropenia in the pediatric oncology unit at the Aga Khan University Hospital (AKUH) in Karachi, Pakistan from January 2011 to December 2012. AKUH is a 600-bed tertiary health care facility. The pediatric oncology unit has 10 beds along with a 5-bed special care unit within the pediatric ward. A total of 11,465 patients were admitted in pediatric oncology unit over the last 7 years with an average of 1638 admissions per year. There is a separate day care facility for chemotherapy administration and transfusion of blood product.

\section{Patient population and definition}

Patients from one month to 16 years of age, who were admitted to the pediatric oncology unit from January 2011 to December 2012 with a diagnosis of prolonged febrile neutropenia were included by using the case definition of (1) new episode of fever, documented or by history (2) absolute neutrophil count (ANC) <0.5 x 109/L; (3) currently under treatment for cancer at our institution and (4) duration of febrile neutropenia $>5$ days. The definitions of fever and neutropenia for this study were adapted as per guidelines of the infectious diseases society of America (IDSA) [7]. Fever is defined as a single oral temperature of $\geq 38.3^{\circ} \mathrm{C}$ or a temperature of $\geq$ $38.0^{\circ}$ sustained over a one hour period, or on more than one occasion in a 24 -hour period. Neutropenia is defined as an absolute neutrophil count (ANC) of less than $0.5 \times 109 / \mathrm{L}$. Bloodstream infection (BSI), and pneumonia in immunocompromised patients were defined according to the criteria established by the Centers for Disease Control/National Healthcare Safety Network (CDC/NHSN) Guidelines [8]. For definition of fungal infections revised criteria for invasive fungal disease from the European Organization for Research and Treatment of Cancer/ Infectious Diseases Mycoses Study Group (EORTC/ MSG) was accepted in this study [9]. The primary outcomes in this study were defined as Composite Adverse Event Outcome (CAEO) which includes patients who required inotropic support and/or admitted to the pediatric intensive care unit (PICU) within 24 hours of their presentation and/or mortality.

\section{Data collection}

All patients who had diagnosis codes for both neoplastic disease [International Classification of Diseases, 9th revision, clinical modification (ICD-9-CM) code 140-239] and febrile neutropenia, and was 16 years of age or younger were identified by using health information management system and included in the analysis. For those patients who had more than one episodes of prolonged febrile neutropenia, each episodes was counted as a separate case. The primary outcomes of this analysis were a) requirement of inotropic support and b) admission to the pediatric intensive care unit (PICU) within 24 hours of presentation. These factors served as markers for severity of illness and mortality in the hospital. Relevant covariate data including demographic features, age, gender, type of malignancy, phase of chemotherapy, clinical features at presentation, duration of symptoms, initial labarotary findings including total white blood cell (WBC) count, absolute neutrophil count (ANC), and platelet count; radiological findings (if applicable) and microbiological results, management and outcomes were also collected. All patients were treated as inpatients following the "International Pediatric Fever and Neutropenia Guideline" [10].

\section{Statistical analysis}

For analysis, SPSS version 20.0 (IBM, Chicago, USA) was used. Death is a rare event in pediatric patients with febrile neutopenia, so we created a composite primary adverse event (AE) outcome11 including in-hospital mortality and/or its antecedents; admission to the pediatric intensive care unit (PICU) within 24 hours of presentation and/or receipt of inotropic support within 24 hours of presentation. Summary statistics were used to describe 
the cohort. Frequencies were computed for qualitative variables, and mean and standard deviation were computed for quantitative variables. Independent risk factors associated with development of adverse effect outcomes were identified by comparing patients with and without composite adverse effect outcomes. A p-value at the univariate level of 0.05 was considered significant. For the multivariate model a $p$-value cut-off of 0.001 along with high crude odds ratio (OR) were taken into account. Finally, a multiple regression model was applied for variables in such a way that the variable with the most significant $p$-value was entered first in the final model to calculate the adjusted odds ratio and confidence interval.

\section{Ethical approval}

The study was approved by the Ethical Review Board (ERB) of Aga Khan University, Karachi.

\section{RESULTS}

The total number of admissions in the pediatric oncology unit during the study period was 2,516 . A total of 872 febrile neutropenia episodes were identified and out of them 135 episodes had PFN. FN and PFN episodes among all pediatric oncology admissions in our study was $34.7 \%$ and $5.3 \%$ respectively.

The study cohort included 135 PFN episodes in 68 patients for final analysis. The number of PFN episode per patient ranged from 1 to 5 ; out of them 32 patients (47.1\%) had single episode, 10 (33.8\%) patients had 2-3 episodes and 3 (19.1\%) patients had 4-5 episodes of PFN. The mean age of the study population was $7.32( \pm 4.1)$ years. There were $98(72.6 \%)$ episodes in males and $37(27.4 \%)$ in females with male: female episodes ratio was 2.6. The mean duration of $\mathrm{FN}$ was $10.3 \pm 5.2$ days (range 1-25 days). Most of the patients had primary diagnosis of acute leukemia $(n=88,65.2 \%)$ and lymphoma $(n=19,14.1 \%)$, followed by solid tumors $(n=28,20.7 \%)$ (Table 1). Pyrexia alone was the most common presenting complaint $(85.6 \%)$ followed by poor oral intake $(50.5 \%)$, vomiting $(15.1 \%)$, respiratory complaints $(12.5 \%)$, mucositis $(11.3 \%)$ and diarrhea (10.6\%).

The causes of neutropenia were identified in 58 (43\%) episodes; BSI in $22(16.3 \%)$, pneumonia 15 (11.1\%), fungal infection $13(9.6 \%)$, infectious diarrhea $5(3.7 \%)$ and UTI in $3(2.2 \%)$ episodes. Additionally, the median neutrophil count and platelet count revealed profound myelosuppression (Table 1). More than $50 \%$ of the patients had hemoglobin level less than $10 \mathrm{gm} / \mathrm{dl}$, absolute neutrophil count (ANC) less than $0.05 \times 109 / \mathrm{L}$, and platelet counts less than $50 \times 109 / L$.

Table 1. Demographic, Clinical and Laboratory characteristics of the study population

\begin{tabular}{|c|c|}
\hline Characteristics & $\begin{array}{c}\text { Episodes number } \\
(\%)\end{array}$ \\
\hline $\begin{array}{l}\text { Gender } \\
\text { Male } \\
\text { Female }\end{array}$ & $\begin{array}{l}98(72.6 \%) \\
37(27.4 \%)\end{array}$ \\
\hline $\begin{array}{l}\text { Age } \\
<5 \text { year } \\
>5 \text { year }\end{array}$ & $\begin{array}{l}96(71.1 \%) \\
39(28.9 \%)\end{array}$ \\
\hline $\begin{array}{l}\text { Cancer Type } \\
\text { ALL } \\
\text { AML } \\
\text { Lymphoma } \\
\text { Sarcomas } \\
\text { Brain tumors } \\
\text { Others }\end{array}$ & $\begin{array}{c}72(53.3 \%) \\
16(11.9 \%) \\
19(14.1 \%) \\
13(9.6 \%) \\
3(2.2 \%) \\
12(8.9 \%)\end{array}$ \\
\hline Blood Stream Infection (BSI) & $22(16.3 \%)$ \\
\hline Pneumonia & $15(11.1 \%)$ \\
\hline Fungal Infection & $13(9.6 \%)$ \\
\hline $\begin{array}{l}\text { Absolute Neutrophil Count } \\
0.25-0.5 \times 109 / \mathrm{L} \\
0.05-0.25 \times 109 / \mathrm{L} \\
<0.05 \times 109 / \mathrm{L}\end{array}$ & $\begin{array}{l}29(21.5 \%) \\
48(35.6 \%) \\
58(42.9 \%)\end{array}$ \\
\hline Hemoglobin level <10 gm/dl & $87(64.4 \%)$ \\
\hline $\begin{array}{l}\text { Platelets count } \\
\quad<50 \times 109 / \mathrm{L} \\
<50 \times 109 / \mathrm{L}\end{array}$ & $\begin{array}{l}66(55.9 \%) \\
52(44.1 \%)\end{array}$ \\
\hline $\begin{array}{l}\text { Composite AE Outcomes }(\mathrm{n}=28) \\
\text { Inotropic Support } \\
\text { PICU Admission } \\
\text { Died }\end{array}$ & $\begin{array}{c}9(6.7 \%) \\
12(8.9 \%) \\
7(5.2 \%)\end{array}$ \\
\hline
\end{tabular}

ALL=Acute Lymphoblastic Leukemia; $A M L=A c u t e ~ M y-$ eloid Leukemia; AE, Adverse Event

The composite AE outcome were observed in $28(20.7 \%)$ patients with in-hospital mortality occurring in 7 (5.2\%), PICU admission in $12(8.9 \%)$ and inotropic support requirement in $9(6.7 \%)$ (Table 1). On logistic regression analysis (Table 2 ) cancer type Acute myeloid leukemia (AML) (Adjusted odds ratio, 7.63 [95\% confidence interval, 1.12-91.35]; $p$ $<0.001$ ), severe neutropenia ANC < $0.05 \times 109 / \mathrm{L}$ (AOR, 10.83 [95\% Cl, 1.37-65.74]; $p<0.001$ ), platelets count $<50 \times 109 / \mathrm{L}$ (AOR, $5.17[95 \% \mathrm{Cl}$, 1.17-23.78 ]; $p<0.001$ ), BSI (AOR, $2.33[95 \% \mathrm{Cl}$, $0.84-15.79] ; p$ 0.05) and fungal infection (AOR, 4.26 [95\% Cl, 1.34-86.57]; $p<0.001)$ were found as independent risk factors associated with development of composite AE outcome in pediatric oncology patients with prolonged $\mathrm{FN}$. 
Table 2. Risk Factors for Composite Adverse Event Outcome in pediatric cancer patients with Prolonged Febrile Neutropenia

\begin{tabular}{|c|c|c|c|c|c|}
\hline Variables & $\begin{array}{c}\text { Without composite } \\
\text { AE outcome, } \\
n=107(\%)\end{array}$ & $\begin{array}{l}\text { With composite } \\
\text { AE outcome, } \\
n=28(\%)\end{array}$ & Crude OR† (Cl) & $p$-value & Adjusted OR (Cl) \\
\hline Gender Male†† & $80(75)$ & $18(64)$ & & & \\
\hline Female & $27(25)$ & $10(36)$ & $1.65(0.68-3.99)$ & 0.267 & -- \\
\hline $\begin{array}{l}\text { Age }<5 \text { yeart† } \\
>5 \text { year }\end{array}$ & $\begin{array}{l}79(74) \\
28(26)\end{array}$ & $\begin{array}{l}17(61) \\
11(39) \\
\end{array}$ & $1.83(0.76-4.37)$ & 0.172 & -- \\
\hline \multicolumn{6}{|l|}{ Cancer Type } \\
\hline ALL†† & $58(54)$ & $14(50)$ & & & \\
\hline AML & $6(6)$ & $10(29)$ & $9.24(2.79-30.6)$ & $<0.001$ & $7.63(1.12-91.35)$ \\
\hline Lymphoma & 17 (16) & $2(7)$ & $0.91(0.23-3.57)$ & 0.598 & -- \\
\hline Sarcomas & $12(11)$ & $1(4)$ & $0.69(0.14-3.42)$ & 0.491 & -- \\
\hline Others & $14(13)$ & $1(4)$ & $0.61(0.12-4.42)$ & 0.532 & -- \\
\hline $\begin{array}{l}\text { Received Chemotherapy } \\
\text { within the preceding } 2 \\
\text { weeks }^{\S}\end{array}$ & $89(83)$ & $19(68)$ & $0.43(0.17-1.09)$ & 0.07 & -- \\
\hline ANC $\left(<0.05 \times 10^{9} / L\right) \S$ & $35(33)$ & $23(82)$ & $9.46(3.32-26.99)$ & $<0.001$ & $10.83(1.37-65.74)$ \\
\hline $\begin{array}{l}\text { Platelets count } \\
\left(<50 \times 10^{9} / \mathrm{L}\right)^{\S}\end{array}$ & $29(27)$ & $23(82)$ & $12.37(4.29-35.60)$ & $<0.001$ & $5.17(1.17-23.78)$ \\
\hline Blood stream Infection§ & $14(13)$ & $8(29)$ & $2.66(0.98-7.18)$ & 0.050 & $2.33(0.84-15.79)$ \\
\hline Pneumonia§ & $11(10)$ & $6(21)$ & $2.38(0.79-7.13)$ & 0.106 & -- \\
\hline Fungal Infection§ & $5(5)$ & $8(29)$ & $8.16(2.41-27.52)$ & $<0.001$ & $4.26(1.34-86.57)$ \\
\hline
\end{tabular}

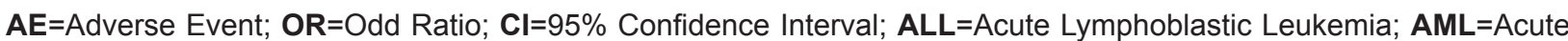
Myeloid Leukemia; $\mathbf{A N C}=$ Absolute Neutrophil Count; $\dagger=$ The odds ratio reflects the risk of composite AE outcome in patients with PFN for each variable; $\uparrow \dagger=$ This is the reference group for the categorical predictor variable; $\S=F o r$ each variable of risk factor, not having the specific risk was used as the reference group.

\section{DISCUSSION}

A number of studies from developed countries have evaluated the risk factors for bacteremia or poor outcomes in children with febrile neutropenia. There has been increasing interest in stratifying these patients into risk categories to establish guidelines for better management $[7,12-14]$. The current study uses a single institution database to identify the risk factors for development of adverse outcomes among PCP with PFN.

Although death is the most devastating of all potential complications of $\mathrm{FN}$, most of the studies use bacteremia or other bacterial infections as the main outcomes variables.[11, 15, 16] A recently published study reported $11.1 \%$ composite AE outcome in FN patients with in-hospital mortality of $(0.7 \%)$, PICU admission (4.7\%), and fluid resuscitation $>40 \mathrm{ml} / \mathrm{kg}$ in (10.1\%).[17] In our series, 7 out of 135 episodes $(5.2 \%)$ of PFN had fatal outcome, $9(6.7 \%)$ required inotropic support and $12(8.9 \%)$ were admitted to PICU for supportive care. Thus over all we found composite AE in 28/135 (20.7\%) episodes. This high mortality was among patients who had PFN episodes. However, the mortality rate in some other pediatric studies of $\mathrm{FN}$ has ranged from $0.7 \%$ to $3.9 \%$ [16, $18-20]$.

In many studies, age group emerged as another significant independent risk factor for both longer hospital stay and death. [13] In the current study, the risk of composite $A E$ outcome was higher in children younger than 5 years compared to those who were older (61\% vs. $39 \%$; OR 1.83$)$, although the result was not statistically significant $(p=0.172)$.

In comparison to ALL, a diagnosis of AML was associated with eight-fold increased risk of overall adverse outcome and four-fold increased risk of death. A similar study reported three-fold longer length of stay as well as death in AML patients as compared to ALL [13]. A diagnosis of lymphoma and sarcomas was associated with a significant reduction in the risk of composite adverse outcome. This is consistent with studies in adult population [5]. Similarly, pediatric studies have identified de-novo or relapsed leukemia as a high risk factors for bacterial infection $[18,20]$. 
Out data also showed that severe myelosuppression was associated with composite AE outcome as patients with more severe neutropenia and thrombocytopenia have a higher risk for $A E[13,21]$. A diagnosis of sepsis or bacteremia conferred a 2.3 -fold increase in the risk ( $13 \%$ vs. $29 \%$; $p=0.05$ ) of composite AE. Both pneumonia (OR: 2.4) and fungal infection (AOR 4.3, $p<0.001$ ) were associated with an increased risk of poor outcomes in our study, as compared to eight-fold and five-fold increased risk of death reported [13].

Limitations of this study include a single center study and retrospective design. Additionally, we did not collect physiologic data (heart rate and blood pressure), which may have furthered our understanding of the poor outcome of children. Finally, we did not attempt to account for baseline level of illness, use of growth factors, type of chemotherapy used, existing co-morbidities, and sources of infection other than bacterial and fungal.

\section{CONCLUSION}

In conclusion, our study indicates that a diagnosis of AML, severe neutropenia, severe thrombocytopenia, BSI and fungal infection should be considered high risk factors associated with development of composite AE outcome in PCP with PFN. The identification of risk factors for poor outcomes may help in devising FN protocols and update guidelines for providing optimum therapy to reduce the cost of cancer care as well as to improve the overall outcomes in children with cancer. Prospective studies of PFN among children enrolled in large cooperative trials may be beneficial in evaluating these risk factors further.

Declaration of Conflicting Interests: The authors declare that they have no conflict of interest.

Financial Disclosure: No financial support was received.

\section{REFERENCE}

1. Ellis M. Febrile neutropenia evolving strategies. Ann NY Acad Sci 2008;1138:329-350.

2. Meckler $\mathrm{G}$, Lindemulder S. Fever and neutropenia in pediatric patients with cancer. Emerg Med Clin North Am 2009;27:525544.

3. Walsh TJ RE, Groll AH, Gonzalez C, Pizzo P. Infectious complications in pediatric cancer patients. In: Pizzo PA, Poplack DG, eds. Principles \& Practice of Pediatric Oncology. 5th ed. Philadelphia, PA: Lippincott Williams \& Wilkens, 2005:12691275.

4. Pizzo PA. Management of fever in patients with cancer and treatment-induced neutropenia. $\mathrm{N}$ Engl $\mathrm{J}$ Med 1993;328:1323-1332.
5. Hughes WT, Armstrong D, Bodey GP, et al: 2002 guidelines for the use of antimicrobial agents in neutropenic patients with cancer. Clin Infect Dis 2002;34:730-751.

6. Ozer H, Armitage JO, Bennett CL, et al: 2000 update of recommendations for the use of hematopoietic colony-stimulating factors: Evidence-based, clinical practice guidelines-American Society of Clinical Oncology Growth and Factors Expert Panel. J Clin Oncol 2000;18:3558-3585.

7. Freifeld AG, Bow EJ, Sepkowitz KA, et al. Clinical practice guideline for the use of antimicrobial agents in neutropenic patients with cancer: 2010 Update by the Infectious Diseases Society of America. Clin Infect Dis 2011;52:427-431.

8. Horan TC, Andrus M, Dudeck MA. CDC/NHSN surveillance definition of health care-associated infection and criteria for specific types of infections in the acute care setting. Am J Infect Control, 2008;36:309-332.

9. De Pauw B, Walsh TJ, Donnelly JP, et al. Fungal Infections Cooperative Group and the National Institute of Allergy and Infectious Diseases Mycoses Study Group (EORTC/MSG) Consensus Group. Clin Infect Dis. 2008 June 15;46:18131821.

10. Lehrnbecher T, Phillips R, Alexander $\mathrm{S}$, et al. Guideline for the management of fever and neutropenia in children with cancer and/or undergoing hematopoietic stem-cell transplantation. J Clin Oncol, 2012;30:p.4427-4438.

11. Santolaya ME, Alvarez AM, Aviles CL, et al. Admission clinical and laboratory factors associated with death in children with cancer during a febrile neutropenic episode. Pediatr Infect Dis J 2007;26:794-798.

12. Mendes AV, Sapolnik R, Mendonca N. New guidelines for the clinical management of febrile neutropenia and sepsis in pediatric oncology patients. J Pediatr (Rio J), 2007;83:S54-63.

13. Basu SK, Fernandez ID, Fisher SG, et al. Length of stay and mortality associated with febrile neutropenia among children with cancer. J Clin Oncol 2005;23:7958-7966.

14. Phillips B, Selwood K, Lane SM, et al. Variation in policies for the management of febrile neutropenia in United Kingdom Children's Cancer Study Group centres. Arch Dis Child 2007;92:495-498.

15. Santolaya ME, Alvarez AM, Aviles CL, et al. Prospective evaluation of a model of prediction of invasive bacterial infection risk among children with cancer, fever, and neutropenia. Clin Infect Dis 2002;35:678-683.

16. Klaassen RJ, Goodman TR, Pham B, Doyle JJ. "Low-risk" prediction rule for pediatric oncology patients presenting with fever and neutropenia. J Clin Oncol 2000;18:1012-1019.

17. Fletcher M, Hodgkiss $\mathrm{H}$, Zhang S, et al. Prompt administration of antibiotics is associated with improved outcomes in febrile neutropenia in children with cancer. Pediatr Blood Cancer 2013;60:1299-306.

18. Santolaya ME, Alvarez AM, Becker A, et al. Prospective, multicenter evaluation of risk factors associated with invasive bacterial infection in children with cancer, neutropenia, and fever. J Clin Oncol 2001; 19: 3415-3421.

19. Rackoff WR, Gonin R, Robinson C, et al. Predicting the risk of bacteremia in childen with fever and neutropenia. J Clin Oncol 1996;14:919-924.

20. Lucas KG, Brown AE, Armstrong D, et al. The identification of febrile, neutropenic children with neoplastic disease at low risk for bacteremia and complications of sepsis. Cancer 1996; 77: 791-798.

21. Timothy M, Bodkyn C. The outcome of febrile neutropenic episodes in paediatric oncology at the Wendy Fitzwilliam Paediatric Hospital. West Indian Med J 2011; 60: 153-157. 